\title{
Can Access to Social Facility Help Poverty Reduction in Agricultural Sector? Evidence from Indonesia
} \author{
Andi Nuddin ${ }^{3}$, Alimuddin Laapo ${ }^{4}$ \\ ${ }^{1}$ Hasanuddin University, Indonesia \\ ${ }^{2}$ Kyoto Prefecture College of Agriculture, Japan \\ ${ }^{3}$ Muhammadiyah University of Parepare, Indonesia \\ 4 Tadulako University, Indonesia \\ * Corresponding author e-mail: arsyad@unhas.ac.id
}

Muhammad Arsyad ${ }^{1}$, Yoshio Kawamura'2, Syarifuddin Yusuf ${ }^{3}$, Muh. Hatta Jamil1,

\author{
How to Cite: Arsyad, M., Kawamura, Y., Yusuf, S., Jamil, M.H., Nuddin, A., \& Laapo, A. \\ (2017). Can Access to Social Facility Help Poverty Reduction in Agricultural Sector? Evidence \\ from Indonesia, Int. J. Agr. Syst. 5(2): 154-165.
}

\begin{abstract}
Poverty in agricultural sector is still becomes a serious issue in developing country, and Indonesia is no exception. Our previous study was focusing on poverty and income (income poverty). This paper, however, deals with a substantive question, can access to social facility (non-income) help poverty reduction in agriculture? The study (also) utilized previous model of Dimensionality Test, Factor and Path Analysis to answer the question. The results show that the higher government transfer source income in terms of Social safety Net Program, the more money for smallholders will be. This leads us to argue that transfer income from the government to the smallholder community can be still considered in maintaining smallholders' daily life, means helping them move out poverty. The better access to social services such as primary public health center (called PUSKESMAS), clean water supplied by PDAM (Local Government Division for Drinking Water Affairs) and secondary school is, the higher the household income will be. Thus, if PUSKESMAS, primary and secondary schools as well as clean water sources are nearer, the less time and money will be spent to travel, then the more household income at hand will be saved. In other words, distance and degree of utilization appear to be a crucial part of these interpretations above. Therefore, it is reasonable to say that the better the access to social services such as public health center, schools and public clean water, the more household income will be and in turn it will alleviate the poverty of smallholders. It is clear that providing better access to social facility can help poverty reduction in agricultural sector.
\end{abstract}

Copyright (C) 2017 IJAS. All rights reserved.

Keywords:

Social facility; poverty; agriculture

\section{Introduction}

Poverty in agriculture sector is a complex phenomenon in developing country and Indonesia is no exception. It has difficulty to measure, not only income poverty but also non-income poverty especially access to social services/facilities, such as education, health and clean water remind unsolved. This is a reason why many options appear to be considered how poverty can be viewed. Rubinson et al. (2017) for example, introduced fuel poverty. Mattioli et al. (2017) developed transport poverty 
and fuel poverty. Rubinson's study found that; firstly, the reduction in fuel poor households has dis- proportionately affected areas with lower housing costs. Secondly, there is a higher prevalence of fuel poverty in urban areas. Finally, the condition is more spatially heterogeneous with fewer 'hot-spots' and 'cold-spots'. As a result, each indicator captures different notions of what it means to be fuel poor, representing particular vulnerabilities, losses of wellbeing and injustices. Poverty is a worldwide problem hit developing countries seriously. Seaweed farmers and cocoa smallholders are a part of the problem to solve, indicating that it have been facing rural coastal and agricultural poverty as long-term issues. Needless to say, the issue was (and still is) stretched out from rural agriculture to rural coastal area and this is a reason why rural poverty cannot be neglected in these countries, needs to pay strong attention on it, in other words (Arsyad et al, 2014). In developing countries where agricultural growth was rapid, sustained, and broadly based growth of farm incomes was sustained despite farm price declines in world markets. Domestic food prices remained low, rural employment diversification was enhanced; and, consequently, poverty reduction was robust (Balisacan, 2007). Another interesting study investigates whether financial development is conducive in poverty reduction (Rewilak, 2017), suggesting the importance of social protection for poverty reduction in times of crisis and potential gains from policy intervention (Kiendrebeogo et al., 2017). It was already studied in elsewhere that, poverty needs specific commitment and political will to attack, not only in local level but also in broad sense, national level.

To get lift the rural poor out of poverty, improved productivity in agriculture, which results in higher per capita output, is needed. Also needed is expanding employment and income-earning opportunities in agriculture-related and other rural non-farm activities. This will accommodate labour released from agriculture as labour requirements per unit of output decline with raising productivity. Also, larger numbers of the rural population need to be employed outside of agriculture in the urban sector as well as in the rural non-agricultural occupations. In fact, the rural nonfarm sector is already a significant source of rural income or employment (Islam, 2006). What is made clear by these explanations is that the rural non-farm sector or nonagricultural income generating activities can also be strongly expected to reduce poverty in terms of income levels for the poor in rural areas. It is a fact that non-income poverty is a more serious problem than income poverty in Indonesia. When one acknowledges all dimensions of human well-being-adequate consumption, reduced vulnerability, education, health and access to basic infrastructure-then almost half of all Indonesians would be considered to have experience at least one type of poverty. Nonetheless, Indonesia has made good progress in past years on some human capital outcomes. There have been notable improvements in educational attainment at the primary school level; basic healthcare coverage (particularly in birth attendance and immunization); and dramatic reductions in child mortality. But in some MDG related indicators Indonesia has failed to make significant progress and lags behind other countries in the region (World Bank, 2006) even if government intervention gone.

Regardless the debate above, the expansion of agricultural sector is needed due to its crucial role in Indonesian economy. In 1999, Daryanto also pointed out some features of agriculture. First, provision of adequate basic need commodities (which include agricultural products) is a strategic priority of the government in order to preserve the conditions of stable rule and legitimacy. Second, the low proportion of imported inputs in the agricultural sector means agriculture has not been as badly affected as other sectors by the crisis. Mounting food imports and foreign exchange constraints have increasingly turned attention towards the need to expand food 
production. Third, the agricultural sector functions as a 'social safety valve', by absorbing some of the retrenched labor, as well as new entrants to the labor force unable to find work in urban areas. Fourth, the agricultural sector can make useful contributions to foreign exchange either by raising a country's earning from exports or by producing agricultural import substitutes. The drastic currency depreciation provides increased opportunities for expanding traditional crops (such as coffee, tea, cocoa beans, fishery and forestry products). Fifth, the agricultural sector is an important potential source of demand for other sectors. A growing agricultural sector will stimulate the demand for industrial products. With increasing incomes in the agricultural sector, the effective demand for domestic manufactured goods would be bolstered (Daryanto, 1999). This leads us to argue that agriculture could be expected to be one of the engines of growth in Indonesian economy, including poverty reduction. However, a crucial issue on poverty lefts behind is non-income poverty. It relies on the facts that, a number of previous studies were focusing on poverty and income (income poverty). This paper, however, deals with a substantive question, can access to social facility (non-income) help poverty reduction in agricultural sector?

\section{Method}

\subsection{Research Site and Sampling}

The research was conducted in Desa Maddenra, Sidrap District, South Sulawesi Province, Indonesia. Two basic criterions of the research site are needed. They are; (1) the average percentage of cocoa smallholders and poor households for selecting district (Criterion 1), and (2) the same percentage in cocoa smallholders, but different in poor households for selecting desa/village (Criterion 2). In order to reach these criterions, by putting the secondary data into XY Scatter Plot, we got the research site. We interviewed $28.20 \%$ of the total cocoa smallholder households.

\subsection{Analysis}

It should be emphasized here that we use same method to explain different issue in previous publication. The study utilized previous model of Dimensionality Test, Factor and Path Analysis.

(i) Test for Dimensionality

In the analysis, Correlation Matrix was used for testing dimensionality. The Pearson Product-Moment Correlation $(r)$ was employed to measure the association among variables as the most widely used correlation index. There are several ways to calculate the Person product moment coefficient correlation, $r_{x y}$. One approach is to define $r_{x y}$ in terms of the covariance (Pett et al., 2003) as follows. The matrix was obtained by computing the correlation among variables selected through the SPSS Program.

$$
r_{x y}=\frac{\operatorname{cov}(x, y)}{\sqrt{\operatorname{var}(x) \operatorname{var}(y)}}=\frac{s_{x y}}{\sqrt{s_{x}^{2} s_{y}^{2}}}=\frac{s_{x y}}{s_{x} s_{y}}
$$

where :

$$
\begin{aligned}
& s_{x y}=\text { sample covariance for items } \mathrm{X} \text { and } \mathrm{Y}, \operatorname{cov}(\mathrm{X}, \mathrm{Y}) \\
& s_{x}^{2}=\text { sample variance for item } \mathrm{X}, \operatorname{var}(\mathrm{X}) \\
& s_{y}^{2}=\text { sample variance for item } \mathrm{Y}, \operatorname{var}(\mathrm{Y}) ; \text { and } \\
& s_{x}=\sqrt{s_{x}^{2}}=\text { the standard deviations for item } \mathrm{X}
\end{aligned}
$$


(ii) Factor Analysis for Index Construction

Three subsequent steps are undertaken in Factor Analysis. They are; (1) extracting factor to meet an initial solution or initial decision regarding the number of inputted factors underlying a set of measured variables in each of the dimensions studied by employing Principal Component Analysis (PCA) as an extraction method (unrotated solution); (2) rotating factor by using Varimax Method--the most common rotation method-- to create the results which are expected more interpretable as a final solution. The consideration is that unrotated solution has unclear meaning, while the rotated factor matrix provides the clear cluster of variables in the dimension constructed; (3) constructing Factor Matrix to calculate "Index" as a new set of variables to be regressed.

(iii) Path Analysis

Path Analysis (PA) basically is standardized General Multiple Regression Analysis (GMRA). A multiple regression equation is a liniear model constructed by a dependent variable and a set of explanatory variables (Kawamura, 1978) to represent reality or phenomenon which can be formulated based on both theoretical framework and emperical evidence. The fundamental different between PA and GMRA is only the nature of data. The data used in PA is standardized. Therefore, the assumption used in PA principally is the same as GMRA assumption. The general model of Path Analysis;

$Y_{t}=\beta_{1} X_{1 t}+\beta_{2} X_{2 t}+\ldots+\beta_{k} X_{k t}+E_{t}$, for $Y_{t}, X_{i t}$ are standardized and $t=1,2, \ldots, n$ yields the following form:

$$
\mathrm{Y}_{\mathrm{t}}=\left(\sum_{q=1}^{K} \beta_{q} X_{q t}\right)+\mathrm{E}_{\mathrm{t}} \text { in which the direct effect of the independent variables on }
$$

each of its respective dependent can be estimated by path equations:

$$
\begin{aligned}
& \mathrm{X}_{1}=\mathrm{E}_{1} \quad \text { (Path Equation 1, PE 1) } \\
& \mathrm{X}_{2}=\mathrm{E}_{2} \quad(\mathrm{PE} 2) \\
& \mathrm{X}_{3}=\mathrm{E}_{3} \quad(\mathrm{PE} 3) \\
& \mathrm{X}_{4}=\mathrm{E}_{4} \quad(\mathrm{PE} 4) \\
& \mathrm{X}_{5}=\mathrm{P}_{51} \mathrm{X}_{1}+\mathrm{P}_{52} \mathrm{X}_{2}+\mathrm{P}_{53} \mathrm{X}_{3}+\mathrm{P}_{54} \mathrm{X}_{4}+\mathrm{E}_{5} \quad(\mathrm{PE} 5) \\
& \mathrm{X}_{6}=\mathrm{P}_{61} \mathrm{X}_{1}+\mathrm{P}_{62} \mathrm{X}_{2}+\mathrm{P}_{63} \mathrm{X}_{3}+\mathrm{E}_{6} \quad(\mathrm{PE} \mathrm{6)} \\
& \mathrm{X}_{7}=\mathrm{P}_{71} \mathrm{X}_{1}+\mathrm{P}_{72} \mathrm{X}_{2}+\mathrm{P}_{74} \mathrm{X}_{4}+\mathrm{P}_{76} \mathrm{X}_{6}+\mathrm{P}_{75} \mathrm{X}_{5}+\mathrm{E}_{7} \quad \text { (PE 7) }
\end{aligned}
$$

The above equations yield a general form, $X_{j}=\left(\sum_{q=1}^{k} P_{j q} X_{q}\right)+E_{j}$ for $(\mathrm{k}<\mathrm{j})$; where $\mathrm{P}_{\mathrm{jq}}$ is path coefficient of the independent variables and $E_{j}$ is error terms. The estimated values in each one of the above path equations can be obtained (from PE 5 to PE 7) by the formula $\hat{X} j=\sum_{q=1}^{k} \hat{P} j q X q,(k<j)$; where a hat $\left(^{\wedge}\right)$ indicates an estimated value. Thus, a path coefficient $P_{j q}$ is a standardized regression coefficient, which is $b_{\mathrm{jq}}{ }^{*}\left(\mathrm{~S}_{\mathrm{xj}} / \mathrm{S}_{\mathrm{xq}}\right)$. In this case, $b_{j q}$ is an unstandardized regression coefficient, while $S_{x j}$ and $S_{x q}$ are, respectively, the standard deviation of $X_{j}$ and of $X_{q}$ (see Kawamura, 1978). This solution leads us to test a Null Hypothesis $\left(\mathbf{H}_{0}\right)$ that "there is no significant effect of independent variables on dependent ones". 


\section{Results and Discussion}

\subsection{Dimensionality Test for Access to Social Facility}

One of the important dimensions deal with poverty is "Access to Social Facility". Before constructing the Factor Matrix, there are seventy variable combinations within this specific dimension as a whole (Table 1). About $28.57 \%$ (twenty out of seventy) variable combinations have significant associations in the dimension. It is true that the number of significant variable within the specific dimension could be an important guide in identifying which dimension is really important in explaining the social phenomenon (poverty issue) in this analysis. However, for some fundamental reasons, including complexity of social phenomenon itself, it is also true that the percentage above (almost 30\%) is still more than enough to clarify the poverty situation from one dimension. Equally importantly, is the association degree between this specific dimension and the other dimensions (how strong the associations are). For this particular consideration, Access to Social Facility Dimension as apparent in Table 1 is very impressive. Why? The association degree between Access to Social Facility Dimension and the other five dimensions ranges between 13.92\% (Agricultural Asset Dimension) - $20.40 \%$ (Household Human Resource) which is closer to the average one $(16.15 \%)$. This leads us to say that Access to Social Facility Dimension has a strong association with the other five dimensions constructed without any larger outlier (good way in constructing dimension, in other words). However, the association degree between the Access to Social Facility Dimension and the poverty is less than $10 \%$. This means that of those variables within the Access to Social Facility Dimension that have significant association to the poverty is less than $10 \%$. This is not without a probable reason. The fundamental way of constructing the dimension (resulting association degree among dimension including poverty) relies on the theoretical consideration and previous studies which do not always exactly represent the real situation of poverty itself as a complex phenomenon. In spite of that, another important point, associated with the Access to Social Facility Dimension, is to identify which dimension is really important outside of this dimension. It was found next, (Table 1) that outside of the Access to Social Facility Dimension constructed, the Household Human Resource Dimension (association degree of $20.40 \%$ ) is much more important in clarifying the poverty issue, followed by the Access to Information Dimension of $(17.14 \%)$, Agricultural Economic Activity (15.00\%), Non-Agricultural Economic Activity (14.28\%) and Agricultural Asset (13.92\%). However, this paper is focusing on Access to Social Facility Dimension and will not explain another 5 dimensions.

Then, for constructing a set of representative factors for the Access to Social Facility Dimension specified, Factor Analysis was also run. For this, the results are displayed in Table 2. It is clearly depicted that fourteen variables were computed in the dimension. They are FRE_HEALT1 (degree of utilization of integrated health post, called "POSYANDU"), FRE_HEALT3 (degree of utilization of primary public health center, so called "PUSKESMAS"), DISTN_HEALT1 (distance to POSYANDU), DISTN_HEALT3 (distance to PUSKESMAS), FRE_WATCO (degree of collecting water for cooking), DISTN_WATCO (distance to the water source for cooking), TIMEL_WATCO (time spent for collecting water for cooking), FRE_WATBW (degree of collecting water for washing/bathing), DISTN_WATBW (distance to the water source for washing/bathing), TIMEL_WATBW (time spent for collecting water for washing/bathing), DISTN_EDUC0 (distance to the Kindergarten), DISTN_EDUC1 (distance to the Primary School), DISTN_EDUC2 (distance to the Junior High School) and DISTN_EDUC3 (distance to the Senior High School). After extracting and rotating by Varimax Method, the factor matrix extracts six factors in which the first four factors 
already account for more than $50 \%$ of the variance of the fourteen variables included. Then, Factor 5 and Factor 6 explain 28.86\% more of the variance of variables included. In terms of contribution to the total variance, the eigenvalue reveals that the six factors account for $69.27 \%$ (almost $70 \%$ ) of the variance of the all variables involved in the Access to Social Facility Dimension. Thereby, these fourteen variables mentioned above, are the representative variables of the six factors extracted in the matrix for this dimension.

Table 1. Test for Dimensionality: Position of Access to Social Facility

\begin{tabular}{|c|c|c|c|c|c|c|c|}
\hline & \multirow[t]{2}{*}{ Dimension } & \multicolumn{6}{|c|}{$\begin{array}{c}\text { Significant Association of Variables } \\
\text { Within \& Between Specific Dimension (\%) }\end{array}$} \\
\hline & & $\mathbf{1}$ & 2 & 3 & 4 & 5 & 6 \\
\hline 1 & $\begin{array}{l}\text { Household } \\
\text { Human } \\
\text { Resource }\end{array}$ & $\begin{array}{r}13 / 21= \\
\left.61.90^{a}\right)\end{array}$ & 26.32 & 20.40 & 12.85 & 11.43 & 3.57 \\
\hline 2 & $\begin{array}{l}\text { Agricultural } \\
\text { Asset }\end{array}$ & $\begin{array}{r}30 / 114= \\
26.32 \\
\end{array}$ & $\begin{array}{r}37 / 89= \\
41.57 a)\end{array}$ & 13.92 & 12.00 & 16.50 & 8.75 \\
\hline 3 & $\begin{array}{l}\text { Access to Social } \\
\text { Facility }\end{array}$ & $\begin{array}{r}20 / 98= \\
20.40\end{array}$ & $\begin{array}{r}39 / 280= \\
13.92\end{array}$ & $\begin{array}{r}20 / 70= \\
28.57 \text { a) }\end{array}$ & $\mathbf{1 7 . 1 4}$ & 15.00 & 14.28 \\
\hline 4 & $\begin{array}{l}\text { Access to } \\
\text { Information }\end{array}$ & $\begin{array}{r}9 / 70= \\
12.85\end{array}$ & $\begin{array}{r}24 / 200= \\
12.00\end{array}$ & $\begin{array}{r}24 / 140= \\
17.14\end{array}$ & $\begin{array}{r}15 / 39= \\
38.46^{\text {a) }}\end{array}$ & 18.28 & 11.84 \\
\hline 5 & $\begin{array}{l}\text { Agricultural } \\
\text { Economic } \\
\text { Activity }\end{array}$ & $\begin{array}{r}8 / 70= \\
11.43\end{array}$ & $\begin{array}{r}33 / 200= \\
16.50\end{array}$ & $\begin{array}{r}21 / 140= \\
15.00\end{array}$ & $\begin{array}{r}17 / 93= \\
18.28\end{array}$ & $\begin{array}{l}5 / 44= \\
11.36^{\text {a) }}\end{array}$ & 7.50 \\
\hline 6 & $\begin{array}{l}\text { Non- } \\
\text { Agricultural } \\
\text { Economic } \\
\text { Activity }\end{array}$ & $\begin{array}{r}2 / 56= \\
3.57\end{array}$ & $\begin{array}{r}14 / 160= \\
8.75\end{array}$ & $\begin{array}{r}16 / 112= \\
\mathbf{1 4 . 2 8}\end{array}$ & $\begin{array}{r}9 / 76= \\
11.84\end{array}$ & $\begin{array}{r}6 / 80= \\
7.50\end{array}$ & $\begin{array}{r}2 / 26= \\
7.69 \text { a) }\end{array}$ \\
\hline & Average $(\%)^{\mathrm{b})}$ & 14.91 & 15.50 & 16.15 & 14.42 & 13.74 & 9.19 \\
\hline & Poverty (\%)c) & 28.57 & 65.00 & 7.14 & 10.00 & 60.00 & 25.00 \\
\hline
\end{tabular}

Note:

a) Association degree of variables within the specific dimension (concept).

b) Average association degree between the specific dimension and the others.

c) Percentage of variable within the specific dimension has significant association with Poverty. 
Table 2. Factor Matrix of the Access to Social Facility Dimension

\begin{tabular}{|c|c|c|c|c|c|c|c|c|c|c|c|c|c|}
\hline & \multicolumn{13}{|c|}{ Factor Matrix } \\
\hline & \multirow{2}{*}{ Com } & \multicolumn{6}{|c|}{ Varimax Rotated Solution } & \multicolumn{6}{|c|}{ Factor Score Coefficient } \\
\hline & & F 1 & F 2 & F 3 & F 4 & F5 & F6 & F 1 & F 2 & F 3 & F 4 & F 5 & F6 \\
\hline FRE HEALT1 & 812 & -.027 & -.081 & -.008 & -.081 & -.893 & .024 & -.027 & -.081 & -.008 & -.081 & -.893 & .024 \\
\hline FRE_HEALT3 & .612 & -.062 & .248 & 699 & .136 & .065 & .188 & -.062 & .248 & 699 & .136 & .065 & .188 \\
\hline DISTN_HEALT1 & .324 & -.014 & .466 & .084 & -.278 & .120 & .090 & -.014 & .466 & .084 & -.278 & .120 & .090 \\
\hline DISTN HEALT3 & .837 & .033 & -.037 & .111 & -.034 & .063 & .904 & .033 & -.037 & .111 & -.034 & .063 & .904 \\
\hline FRE WATCO & .534 & -.184 & -.085 & -.618 & .318 & .089 & -.040 & -.184 & -.085 & -.618 & .318 & .089 & -.040 \\
\hline DISTN_WATCO & .821 & -.008 & .902 & .049 & .044 & -.038 & .039 & -.008 & .902 & .049 & .044 & -.038 & .039 \\
\hline TIMEL_WATCO & .831 & .891 & -.059 & -.060 & .119 & .072 & .097 & .891 & -.059 & -.060 & .119 & .072 & .097 \\
\hline FRE_WATBW & .633 & .002 & -.195 & -.292 & .662 & -.168 & .209 & .002 & -.195 & $\begin{array}{l}-292 \\
\end{array}$ & .662 & -.168 & .209 \\
\hline DISTN_WATBW & .807 & -.020 & .883 & .017 & -.024 & -.033 & -.155 & -.020 & .883 & .017 & -.024 & -.033 & -.155 \\
\hline TIMEL_WATBW & .694 & .695 & -.053 & -.075 & .043 & .068 & -.444 & .695 & -.053 & -.075 & .043 & .068 & -.444 \\
\hline DISTN_EDUC0 & .685 & .070 & -.075 & .016 & -.357 & .732 & .102 & .070 & -.075 & .016 & -.357 & .732 & .102 \\
\hline DISTN_EDUC1 & .735 & .823 & .050 & .195 & -.083 & -.022 & .098 & .823 & .050 & .195 & -.083 & -.022 & .098 \\
\hline DISTN_EDUC2 & .641 & -.005 & -.108 & .790 & .062 & .032 & -.025 & -.005 & -.108 & .790 & .062 & .032 & -.025 \\
\hline DISTN_EDUC3 & .732 & .083 & .008 & .219 & .805 & -.032 & -.167 & .083 & .008 & 219 & .805 & -.032 & -.167 \\
\hline \multicolumn{2}{|l|}{ Eigenvalue } & 2.007 & 1.951 & 1.698 & 1.447 & 1.408 & 1.186 & & & & & & \\
\hline \multicolumn{2}{|c|}{ Percent of Variance $(1)^{a)}$} & 14.336 & 13.939 & 12.127 & 10.335 & 10.055 & 8.472 & & & & & & \\
\hline \multicolumn{2}{|c|}{ Cum of Variance $(2)^{b)}$} & 14.336 & 28.275 & 40.402 & 50.737 & 60.792 & 69.265 & & & & & & \\
\hline
\end{tabular}

Based on their factor coefficient, the variables TIMEL_WATCO, TIMEL_WATBW and DISTN_EDUC1, (as clearly depicted in Table 2), are strongly loaded on Factor 1 with factor coefficient ranging between .700 and .891 . The object of the first two variables is the same (time spent for collecting water for cooking, washing and bathing), including their measurement units, while the variable DISTN_EDUC1 refers to the distance to primary school. Since the water resources for cooking, washing and bathing as well as primary education are social basic needs, this leads us to name Factor 1 as "Social Basic Needs". Next, the variable DISTN_WATCO and DISTN_WATBW are strongly loaded on Factor 2 with factor coefficient of .902 and .883. For the same reason on Factor 5 of the Agricultural Asset Dimension, even if the variable DISTN_HEALT1 has factor coefficient of .466, the variable was still kept for the next analysis under Factor 2 in which these three variables focus on the distance to social services. Thereby, we simply name Factor 2 as "Distance to Social Services". Similarly, there are also three variables, which are strongly loaded on Factor 3 . These variables are FRE_HEALT3 (with factor coefficient of .700), FRE_WATCO (.618) and DISTN_EDUC2 (.790). The first refers to the degree of utilization of primary health center (called PUSKESMAS) as one of the social services, while the variable FRE_WATCO describes the degree of utilization of water source for cooking as a basic need for the smallholders. In the research area, clean water is a part of the scarce resources.

Therefore, local government was (and still is) providing the public water as a social service (but it is not as popular as education and health in Indonesia) for the smallholders (even if in the smaller unit), which has been handled by PDAM (local government for drinking water affairs). The last variable, DISTN_EDUC2, refers to the junior high school which is also a famous social service utilized in Indonesia. In fact, the nature of these three variables concern on the social services utilization in the community daily lives. This consideration leads us to name Factor 3 as "Social Services Utilization".

The next factor extracted in the Access to Social Facility Dimension was Factor 4 . It is important to reemphasize that up to this factor, it accounts for more than $50 \%$ of the variance of the fourteen variables involved. Then, Factor 5, and Factor 6 explain 18.53\% more of the variance of the variables included. By looking at Table 2, it is clearly presented that in terms of their factor coefficient, two variables are strongly loaded on 
Factor 4. They are the following; FRE_WATBW and DISTN_EDUC3. Under Factor 4, all the two variables have the important point i.e. degree of utilization and distance issues. The first variable refers to the degree of collecting water for washing and bathing, while the last refers to the distance to Senior High School as a social facility. To cover explanation on this degree and distance issues (access in other words), we name Factor 4 as "Access to Social Facility". Meanwhile, the variable FRE_HEALT1 and DISTN_EDUC0, are strongly loaded on Factor 5 with factor coefficients ranging between .732 and .893 . Unlike the five factors already discussed, the last factor (Factor 6) has only one variable strongly loaded. The variable DISTN_HEALT3 with factor coefficient more than $90 \%$ refers to the distance to primary public health center called PUSKESMAS so that Factor 6 is named as "Distance to PUSKESMAS". The results of Factor Analysis above were used for further analysis below.

\subsection{Access to Social Facility and Poverty Reduction}

It is important to note that the study used an intermediate variable "Government Transfer Source Income" as an initial step in explaining role of access to social facility on the poverty. It means that independent variables will send their effect to the Government Transfer Source Income, and in turn will affect to the poverty situation. In other words, independent variable will send direct and indirect effect to the poverty. As shown in Figure 1, intermediate variable in the model is Government TransferSource Income $\left(\mathrm{X}_{62 \mathrm{~m}}\right)$. There are five independent variables that have direct effects on "Government Transfer-Source Income $\left(\mathrm{X}_{62 \mathrm{~m}}\right)$ " Three out of five variables have direct positive effects i.e. "Farm Equipment $\left(\mathrm{X}_{22 \mathrm{~m}}\right)$ ", "Cocoa and Irrigated Paddy Field Area with Farm Equipment $\left(X_{24 m}\right)$ " and "Distance to PUSKESMAS $\left(X_{36 \mathrm{~m}}\right)$ ". These three variables, that have direct positive effects, can be classified into a moderate effect in our interval. However, the variable Farm Equipment $\left(X_{24 m}\right)$ has the highest effects $(\beta=$ .372) followed by "Cocoa and Irrigated Paddy Field Area with Farm Equipment $\left(X_{24 m}\right.$, $\beta=.322)$ " and "Distance to PUSKESMAS $\left(X_{36 \mathrm{~m}}\right.$, with $\left.\beta=.223\right)$ ". Statistically, some possible interpretations associated with these results can be explored.

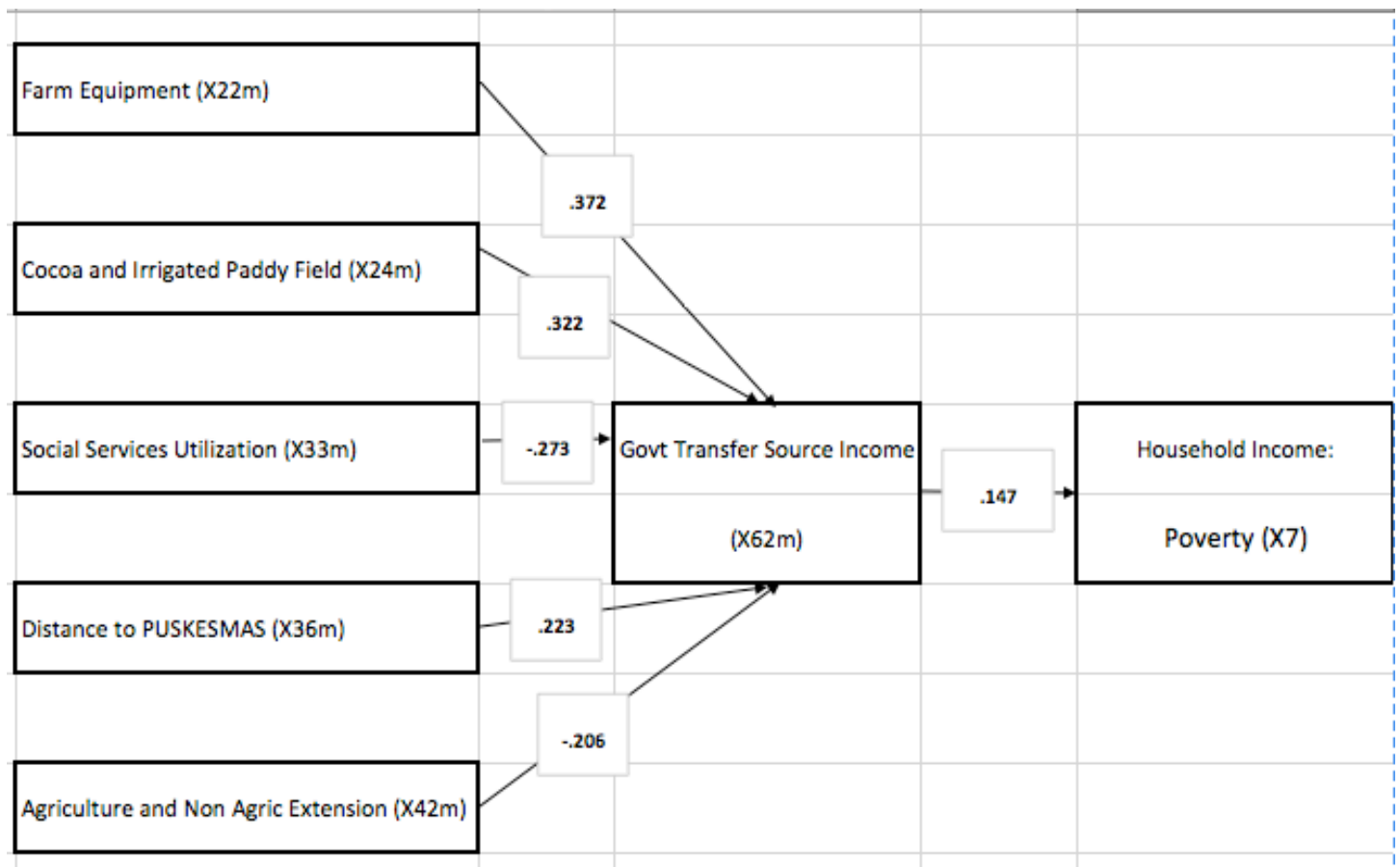

Figure 1. Effect of Independent Variables on the Poverty through Intermediate 
Firstly, we may say that the larger the cocoa and irrigated paddy field areas with farm equipment is see also the variable Farm Equipment $\left.\left(X_{24 m}, \beta=.322\right)\right\}$, the higher the government transfer-source income will be. This is a true phenomenon. The meaning of the variable Government Transfer-Source Income $\left(X_{62 m}\right)$ is household income coming from the government. At the same time, it is also generally true that the Indonesian government has been providing, not only financial support (cash transfer) to the poor household, especially in rural area such as Social Safety Net Program including Highest Oil Price Compensation, but also the government subsidizes the agricultural sector through agricultural input such as fertilizer, chemical pesticide and irrigation infrastructure as well as farm equipment (especially for paddy field) to the smallholders. It means that the larger the paddy field area is, the higher the transfer income, from the government to smallholders is required.

Secondly, the variable Distance to PUSKESMAS, acronym for Primary Public Health Center, $\left(X_{34}, \beta=.223\right)$ also sends positive direct effect on "Government Transfer-Source Income $\left(\mathrm{X}_{62 \mathrm{~m}}\right)$ ". The interpretation of this could be that the further the PUSKESMAS, the higher the government transfer-source income to the smallholders will be. This is also an understandable fact. The PUSKESMAS is located further from the smallholder community and often used by the smallholders' family, meaning that this social facility is also important. This situation requires the government to provide PUSKESMAS closer to the smallholders, which means that the smallholders need the government transfer-source income. Thus, it is a reasonable result that the further the PUSKESMAS, the higher the government transfer-source income will be expected.

Besides direct positive effects, the intermediate variable Government TransferSource Income $\left(\mathrm{X}_{62 \mathrm{~m}}\right)$ also receives direct negative effects from two independent variables in the model of Figure 1. These variables are; "Social Service Utilization $\left(X_{33 \mathrm{~m}}\right)$ " and "Agriculture \& Non-Agriculture Extension $\left(\mathrm{X}_{42 \mathrm{~m}}\right)$ ". However, the first variable has a higher standardized path coefficient ( $\beta$ weight $=-.273)$, and a moderate effect in the interval compared to the latter ones (lower $\beta$ weight indicating a weaker effect). This tells us that the variable Social Service Utilization $\left(X_{33 \mathrm{~m}}\right)$ is much more important than the variable Agriculture \& Non-Agriculture Extension $\left(X_{42 \mathrm{~m}}\right)$, for the community, especially in explaining "Government Transfer-Source Income $\left(\mathrm{X}_{62 \mathrm{~m}}\right)$ ". The interpretation could be that the less access to social services such as public health center, clean water and education facilities, the higher the government transfer-source income will be. This is also a persuasive result. The further the health and education facilities as well as clean water are; the more the government spending (nation public expenditure) on these facilities is allocated, so that rural smallholders also benefits from the expenditure in the health and education sectors. For instance, the secondary school and primary public health center are still located far from the smallholder residences. As we also already explained, beside primary school and auxiliary public health center (so called PUSTU), the secondary school and primary public health center (so called PUSKESMAS) are also more often used by the smallholders' families. It means that, these two latter social facilities are also important. This situation requires the government to provide secondary school and PUSKESMAS closer to the smallholders in rural areas, which means that government transfer-source income is needed by the smallholders, as Van de Walle (1992) concluded in her study for the World Bank on the distribution of the benefit from social services in Indonesia. She found that within the education sector, subsidies to primary and to a lesser extent lower secondary education will do most to reach poorer households and raise their living standards. This is also a potentially important conduit for attaining relatively 
isolated rural households. Within the health sector, subsidies to basic primary health care provide the best option for reaching the poor.

Then, intermediate variable Government Transfer-Source Income sends direct effects $\left(X_{62}, \beta=.147\right)$ on "Household Income $\left(X_{7 m}\right)$ ". Even if this variable has standardized path coefficients ( $\beta$ weight) relatively weak in our intervals--meaning weaker or smaller effects, the variable gives crucial information in order to understand the nature of poor household income as a whole. For this, we may say that the higher the government transfer-source income is, the more money (cash transfer) will be received by the poor household to help in their daily lives. This is also a true phenomenon. The meaning of the variable Government Transfer-Source Income $\left(\mathrm{X}_{62 \mathrm{~m}}\right)$, in this case, is the household income received from the government transfer. Thus, the transfer income appears to be a crucial part of this interpretation. As we previously mentioned, it is also generally true that the Indonesian government has been providing, not only financial support (cash transfer) to the poor households especially in rural area, such as Social Safety Net Program, but also the government subsidizes the agricultural sector through agricultural input such as fertilizer and chemical pesticide as well as farm equipment (especially for paddy field development) to the smallholders. Therefore, it is reasonable to say that the higher the transfer income from government is, the more money for smallholders will be. This leads us to argue that transfer income from the government to the smallholder community can be still considered in maintaining smallholders' daily life, means helping them move out poverty.

Besides these direct effect of intermediate variables on "Household Income $\left(X_{7 m}\right)$ ", as shown in Figure 1, there are also seven independent variables \{Family Structure with Education $\left(X_{12 m}\right)$, Cultivated Land Area with Farm Equipment $\left(X_{21 m}\right)$, Farm Equipment $\left(X_{22 m}\right)$, Coffee and Paddy Field Area with Farm Equipment $\left(X_{25 m}\right)$, Paddy Upland Area $\left(X_{27 m}\right)$, Social Service Utilization $\left(X_{33 m}\right)$ and Agriculture \& NonAgriculture Extension $\left.\left(\mathrm{X}_{42 \mathrm{~m}}\right)\right\}$ that send their significant direct effects on "Household Income $\left(X_{7 m}\right)$ ". Five out of seven variables have direct positive effects i.e. the variable Family Structure with Education $\left(X_{12 m}\right)$, Cultivated Land Area with Farm Equipment $\left(X_{21 m}\right)$, Farm Equipment $\left(X_{22 m}\right)$, Social Service Utilization $\left(X_{33 m}\right)$ and Agriculture \& NonAgriculture Extension $\left(\mathrm{X}_{42 \mathrm{~m}}\right)$. Of these five variables that have direct positive effects, the variable Social Service Utilization $\left(\mathrm{X}_{33 \mathrm{~m}}\right)$ has a stronger effect $(\beta=.444)$ followed by the variable Cultivated Land Area with Farm Equipment $\left(X_{21 m}, \beta=.373\right)$, Agriculture \& Non-Agriculture Extension $\left(X_{42 \mathrm{~m}}, \beta=.276\right)$, Farm Equipment $\left(X_{22 \mathrm{~m}}, \beta=.245\right)$ and Family Structure with Education $\left(X_{12 \mathrm{~m}}, \beta=.242\right)$. These latter four variables are categorized into the moderate effects in our interval of $\beta$ weights.

We may interpret that the better the access to social services such as primary public health center (called PUSKESMAS), clean water supplied by the PDAM (Local Government Division for Drinking Water Affairs) and secondary school is, the higher the household income will be. In the research area, within the health sector for instance, PUSKESMAS are more often used by the smallholders' families including primary and secondary school for their kids as well as public clean water for drinking provided by PDAM. Thus, if PUSKESMAS, primary and secondary schools as well as clean water sources are nearer, the less time and money will be spent to travel, then the more household income at hand will be saved. In other words, distance and degree of utilization appear to be a crucial part of these interpretations above. Therefore, it is reasonable to say that the better the access to social services such as public health center, schools and public clean water, the more household income will be and in turn it will alleviate the poverty of smallholders. Based on the standardized path 
coefficients ( $\beta$ weights), the variable Social Service Utilization $\left(X_{33 \mathrm{~m}}\right)$ has the stronger direct positive effect on "Household Income $\left(X_{7 m}\right)$ " in this community. Given this finding, we may argue that from the independent variables side--that have significant direct positive effects on "Household Income $\left(X_{7 \mathrm{~m}}\right)$ "-- the variable Social Service Utilization $\left(\mathrm{X}_{33 \mathrm{~m}}\right)$ is the most important independent variable in explaining the variance of "Household Income $\left(\mathrm{X}_{7 \mathrm{~m}}\right)$ ", or the poverty situation in other words. Now, this also suggests that providing better access to social service facilities--notably public health center, school and public clean water nearer to the smallholder community-- should be considered in order to save much more household income so that the poverty situation can be gradually reduced.

\section{Conclusion}

Some crucial findings: the higher the transfer income from government (government transfer source income) in terms of Social safety Net Program, the more money for smallholders will be. This leads us to argue that transfer income from the government to the smallholder community can be still considered in maintaining smallholders' daily life, means helping them move out poverty. The better the access to social services such as primary public health center (called PUSKESMAS), clean water supplied by the PDAM (Local Government Division for Drinking Water Affairs) and secondary school is, the higher the household income will be. Thus, if PUSKESMAS, primary and secondary schools as well as clean water sources are nearer, the less time and money will be spent to travel, then the more household income at hand will be saved. In other words, distance and degree of utilization appear to be a crucial part of these interpretations above. Therefore, it is reasonable to say that the better the access to social services such as public health center, schools and public clean water, the more household income will be and in turn it will alleviate the poverty of smallholders. It is clear that providing better access to social facility can help poverty reduction in agriculture sector.

\section{References}

Arsyad, M., A. Nuddin, M.Y. Zamhuri, S. Yusuf, (2014). The Poverty Reality of Coastal and Agriculture: How Severe the Seaweed Farmers and Cocoa Smallholders. International Journal of Agriculture System, 2(2):119-131.

Balisacan, A.M., (2007). Why Does Poverty Persist in the Philippines? Facts, Fancies, and Policies. Southeast Asian Regional Center for Graduate Study and Research in Agriculture (SEARCA). Los Banos.

Daryanto, A., (1999). Indonesia's Crisis and the Agricultural Sector: The Relevance of Agricultural Demand-Led Industrialisation. UNEAC Asia Papers, 62(2): 61-72.

Islam, N., (2006). Reducing Rural Poverty in Asia: Challenges and Opportunities for Microenterprises and Public Employment Schemes. Food Products Press.NY.

Kawamura, Y., (1978). Urbanization, Part-Time Farm Households and Community Agriculture: Japan's Experience after World War II. Ph.D. Thesis, Cornell University.

Kiendrebeogo, Y., K. Assimaidou, A.Tall (2017). Social Protection for Poverty Reduction in Times of Crisis. Journal of Policy Modeling, 39(6):1163-1183.

Mattioli, G., K. Lucas, G. Marsden (2017). Transport Poverty and Fuel Poverty in The UK: From Analogy to Comparison. Transport Policy 59 (2017) 93-105.

Pett, M.A., N.R. Lackey \& J.J. Sullivan (2003). Making Sense of Factor Analysis: The Use of Factor Analysis for Instrument Development in Health Care Research. Sage Publications, London. 
Rewilak, J. (2017). The Role of Financial Development in Poverty Reduction. Review of Development Finance 7 (2017) 169-176

Robinson, C., S. Bouzarovski, S. Lindley (2017). Getting the Measure of Fuel Poverty': The Geography of Fuel Poverty Indicators in England. Energy Research and Social Sciencies, in press.

Walle, D.v.d., (1992). The Distribution of the Benefits from Social Services in Indonesia, 1978-87. Policy Research Working Paper. World Bank.

World Bank, (2006). Making the New Indonesia Work for the Poor. World Bank, Jakarta. 